\title{
Urocortin is a novel regulator of osteoclast differentiation and function through inhibition of a canonical transient receptor potential 1-like cation channel
}

\author{
Charlotte E Combs, Karen Fuller, Hashethra Kumar, Anthony P Albert, Grisha Pirianov, \\ James McCormick ${ }^{\mathbf{1}}$, Ian C Locke ${ }^{\mathbf{2}}$, Timothy J Chambers and Kevin M Lawrence \\ Department of Cellular Pathology, St George's, University of London, Cranmer Terrace, London SW17 ORE, UK \\ ${ }^{1}$ Medical Molecular Biology Unit, Institute of Child Health, University College London, London WC1N 1EH, UK \\ ${ }^{2}$ Department of Biomedical Sciences, University of Westminster, 115 New Cavendish Street, London W1W 6UW, UK \\ (Correspondence should be addressed to K M Lawrence; Email: k.lawrence@sgul.ac.uk)
}

\begin{abstract}
This study investigated the role of urocortin (UCN), a member of the corticotrophin-releasing factor (CRF) family of peptides, in osteoclast maturation and function. We found that $10^{-7} \mathrm{M}$ UCN significantly $(P<0 \cdot 05)$ suppressed osteoclast differentiation from bone marrow precursor cells in culture and reduced the expression of several osteoclastic markers. Furthermore, UCN potently suppressed osteoclast bone resorption, by significantly inhibiting both the plan area of bone resorbed by osteoclasts and actin ring formation within osteoclasts at $10^{-9} \mathrm{M}(P<0 \cdot 05)$, with complete inhibition at $10^{-7} \mathrm{M}(P<0 \cdot 001)$. UCN also inhibited osteoclast motility $\left(10^{-7} \mathrm{M}\right)$ but had no effect on osteoclast survival. Osteoclasts expressed mRNA encoding both UCN and the CRF receptor $2 \beta$ subtype. Pre-osteoclasts however,
\end{abstract}

expressed CRF receptor $2 \beta$ alone. Unstimulated osteoclasts contained constitutively active cation channel currents with a unitary conductance of 3-4 pS, which were inhibited by over $70 \%$ with UCN $\left(10^{-7} \mathrm{M}\right)$. Compounds that regulate calcium signalling and energy status of the cell, both crucial for osteoclast activity were investigated. The non-selective cation channel blockers, lanthanum $\left(\mathrm{La}^{3+}\right)$ and gadolinium $\left(\mathrm{Gd}^{3+}\right)$, inhibited actin ring formation in osteoclasts, whereas modulators of voltage-dependent $\mathrm{Ca}^{2+}$ channels and $\mathrm{K}_{\text {ATP }}$ channels had no effect. These findings show for the first time that $\mathrm{UCN}$ is a novel anti-resorptive molecule that acts through a direct effect on osteoclasts and their precursor cells.

Journal of Endocrinology (2012) 212, 187-197

\section{Introduction}

Urocortin (UCN) is a member of the corticotrophinreleasing factor (CRF) family of peptides. It was originally cloned from a rat brain cDNA library, using a probe homologous to CRF (Vaughan et al. 1995). Since then, two new members have been isolated, UCN 2 and 3, which are equivalent to human stresscopin-related peptide and stresscopin respectively (Hsu \& Hsueh 2001, Lewis et al. 2001, Reyes et al. 2001, Fekete \& Zorrilla 2007). All three UCNs are synthesised as precursors of $\sim 200$ amino acids, which are then subsequently cleaved to yield the active peptides, which in the case of UCN is 40 amino acids (Fekete \& Zorrilla 2007). The level of functional availability of UCN is closely regulated by a high affinity CRF-binding protein (CRF-BP), expressed at both release and activation sites of UCN, which acts as a decoy receptor to terminate the ligand signal (Behan et al. 1995, Seasholtz et al. 2002).

UCN binds to two G-protein-coupled receptor subtypes, CRF receptor 1 (CRFR1) and CRFR2, with further receptor diversity produced by alternative RNA splicing (Chen et al. 1993, Lovenberg et al. 1995, Perrin \& Vale 1999, Hauger et al. 2003, Fekete \& Zorrilla 2007). Radioligand binding studies have demonstrated that CRF and UCN can bind to both CRFR 1 and CRFR2, whereas UCN 2 and 3 bind exclusively to CRFR2. UCN has been shown to act predominantly through both $\mathrm{G}_{\alpha \mathrm{s}}$ and $\mathrm{G}_{\alpha \mathrm{q}} \mathrm{G}$-protein subunits to stimulate diverse signalling cascades, through respectively, adenylate cyclase (AC) and phospholipase C (PLC) pathways, depending on the tissue type (Grammatopoulos et al. 2000, Cantarella et al. 2001, Graziani et al. 2002, McEvoy et al. 2002, Bayatti et al. 2003, Karteris et al. 2005). $\mathrm{UCN}$-mediated activation of these signal transduction pathways modulates a variety of end effectors including ion channels involved in calcium signalling and energy metabolism, such as L-type voltage-gated calcium channels, store-operated channels and $\mathrm{K}_{\mathrm{ATP}}$ channels (Lawrence et al. 2002, Tao et al. 2004, 2006, Smani et al. 2007).

The CRF family members have been linked to a number of physiological and pathological conditions. CRF is the classic 
mediator of the hypothalamic stress response, initiating an anxiogenic, neuroendocrine and behavioural stress phenotype. In contrast, UCN plays a more anxiolytic role in this response and is also involved in appetite suppression and energy metabolism (Spina et al. 1996, Smagin et al. 1998, Tanaka et al. 2009). The peptides are also expressed in peripheral tissue, where they appear to be cytoprotective through CRFR2, in models of cellular stress (Brar et al. 2002, Lawrence \& Latchman 2006). Recently, UCN has been found to be elevated in the synovial fluid of patients with rheumatoid arthritis (Kohno et al. 2001, Uzuki et al. 2001) and has also been linked to a reduction in inflammation and bone erosion in a mouse model of this disease (Gonzalez-Rey et al. 2007). However, there is little information on the role of UCN in the physiology or pathology of bone. Because UCN is the only member of this family capable of binding to both CRFR1 and 2, its use would give the best chance of detecting an effect on osteoclasts.

Osteoclasts are derived from the monocyte macrophage lineage; they are large multinucleated cells and are the only cells of the body capable of resorbing bone. They mature to form large tartrate-resistant acid phosphatase (TRAP) positive, multinucleated cells in the presence of receptor activator of NFK B ligand (RANKL) and macrophage colony stimulating factor (M-CSF). Upon activation, osteoclasts locate to the bone surface and initiate resorption by creating a sealing zone, which is accompanied by a ruffled border and actin reorganisation (Väänänen et al. 2000). Excessive resorption by these cells is the cause of several common diseases of bone, including osteoporosis.

In this study we investigated the effects of UCN on the formation and function of osteoclasts. Our results clearly demonstrate that $\mathrm{UCN}$ is a regulator of osteoclast resorption, by suppressing osteoclast maturation and potently inhibiting osteoclastic function. Furthermore, we provide evidence that the inhibitory action of UCN on osteoclasts is mediated by suppression of constitutively active cation channels that have properties characteristic of a canonical transient receptor potential 1 (TRPC1) channel.

\section{Materials and Methods}

\section{Culture media and reagents}

Cells were incubated in minimum essential medium (MEM) with Earle's salts, supplemented with 10\% FCS, $2 \mathrm{mM}$ glutamine, $100 \mathrm{IU} / \mathrm{ml}$ benzylpenicillin and $100 \mu \mathrm{g} / \mathrm{ml}$ streptomycin, UCN (all from Sigma), unless stated otherwise. Recombinant human $\mathrm{M}-\mathrm{CSF}$ and soluble recombinant murine RANKL were purchased from PeproTech EC (London, UK). Recombinant murine interleukin $1 \alpha$ (IL1 $\alpha$ ) and purified human transforming growth factor- $\beta 1$ (TGF- $\beta 1$ ) were obtained from R\&D Systems (Abingdon, Oxon, UK). Osteoblastic MC3T3-E1 cell line was from Bioresource Centre (Ibaraki, Japan). Cell incubations were performed at $37{ }^{\circ} \mathrm{C}$ in $5 \% \mathrm{CO}_{2}$ in humidified air, unless stated otherwise. Slices of bovine cortical bone were prepared as previously described (Fuller et al. 2006).

\section{Generation of osteoclasts}

Osteoclast suspensions were prepared from murine bone marrow cells as previously described (Fuller et al. 2006). Briefly, MF1 mice (4-8 weeks old) were killed by cervical dislocation in accord with Home Office Ethical Guidelines. Femora and tibiae were aseptically removed and dissected free of adherent soft tissue. The bone ends were removed and the marrow cavity was flushed out into a Petri dish by slowly injecting PBS at one end of the bone using a sterile 25-gauge needle. The bone marrow suspension was passed repeatedly through a 21-gauge needle to obtain a single cell suspension. Bone marrow cells were then washed, re-suspended in MEM/FCS, and incubated at a density of $3 \times 10^{5}$ cells $/ \mathrm{ml}$ for $24 \mathrm{~h}$ in a $75 \mathrm{~cm}^{2}$ flask (Greiner Bio-One, Stonehouse, Gloucestershire, UK) containing M-CSF (50 ng/ml), to deplete the cell preparations of stromal cells. Non-adherent cells were collected by centrifugation and used immediately (pre-osteoclasts) or added to $90 \mathrm{~mm}$ diameter cell culture dishes (Greiner) in MEM/FCS, containing M-CSF (50 ng/ml), RANKL $(30 \mathrm{ng} / \mathrm{ml})$ and TGF- $\beta 1 \quad(0 \cdot 1 \mathrm{ng} / \mathrm{ml})\left(7 \cdot 2 \times 10^{6}\right.$ cells in $25 \mathrm{ml}$ for each dish). Cultures were incubated for 5 days, when osteoclast numbers are maximal. Cells were fed every $2-3$ days by replacing $15 \mathrm{ml}$ of culture medium with an equal volume of fresh medium and cytokines. When multinuclear cells had formed, the medium was removed and the cell layer washed three times with PBS without calcium and magnesium. Six millilitres of $0 \cdot 02 \%$ EDTA were added to the dish and cells incubated for $20 \mathrm{~min}$ at room temperature. The EDTA was then removed from the dish and replaced with $4 \mathrm{ml}$ calcium/magnesium-free PBS. A cell scraper (Greiner) was used to scrape the cells into the PBS, and the resulting cell suspension was agitated using a pipette to ensure uniform cell dispersal for further use as described below.

\section{Assessment of bone resorption and actin ring formation}

Seventy-five microlitres of osteoclast-containing cell suspension were added to wells of a 96-well plate (Greiner), each of which contained a bone slice in $75 \mu \mathrm{l}$ MEM/FCS. Cells were allowed to sediment for $20 \mathrm{~min}$ at $37^{\circ} \mathrm{C}$ before the bone slices were washed in PBS and transferred to fresh wells. Cells for assessment of resorption were incubated for $4 \mathrm{~h}$ in $200 \mu \mathrm{l} \mathrm{MEM} / \mathrm{FCS}$ in the presence of M-CSF (50 ng/ml), RANKL (30 ng/ml), IL1 $\alpha(10 \mathrm{ng} / \mathrm{ml})$ with UCN $\left(10^{-7}-10^{-10} \mathrm{M}\right)$ or vehicle. Osteoclasts for assessment of actin ring formation were incubated for $4 \mathrm{~h}$ in M-CSF, RANKL and IL $1 \alpha$ as above, before addition of UCN $\left(10^{-7}-10^{-10} \mathrm{M}\right)$ or vehicle. Incubation was then continued for $30 \mathrm{~min}$. In some actin ring formation experiments, ion channel modulators were also included. 
To measure bone resorption, bone slices were immersed in $10 \%(\mathrm{v} / \mathrm{v})$ sodium hypochlorite for $10 \mathrm{~min}$ to remove cells, washed, air-dried, mounted onto stubs for scanning electron microscopy and sputter coated with gold. The entire surface of each bone slice was examined blind and the total area resorbed per bone slice was quantified by scanning electron microscopy (S90: Cambridge Instruments, Cambridge, UK).

For assessment of actin rings, bone slices were fixed in 10\% formalin. Cells were permeabilised with $0 \cdot 1 \%$ Triton X-100 for $5 \mathrm{~min}$, washed three times in PBS and then incubated with FITC-conjugated phalloidin $(1 \mu \mathrm{g} / \mathrm{ml})$ for $45 \mathrm{~min}$ at $37^{\circ} \mathrm{C}$. Bone slices were washed three times in PBS and mounted onto slides in fluorescence mounting medium (Dako, Ely, Cambridge, UK). Actin rings were visualized using a Zeiss fluorescent microscope and the numbers of actin rings in ten fields per bone slice were counted.

\section{Assessment of osteoclast motility}

Four hundred and fifty microlitres of osteoclast-containing cell suspension were added to 24-well plate wells (Greiner) containing $13 \mathrm{~mm}$ diameter glass coverslips in $450 \mu \mathrm{l}$ MEM/FCS and cells were allowed to sediment for $20 \mathrm{~min}$ in an incubator. Coverslips were washed and transferred to 25 $\mathrm{cm}^{2}$ tissue flasks (Greiner). Cells were allowed to equilibrate for a minimum of $1 \mathrm{~h}$ in $4.5 \mathrm{ml} \mathrm{MEM} / \mathrm{FCS}$ then flasks were sealed and placed in an incubation chamber of an Olympus 1MT-373 inverted microscope (Gallenkamp and Co., Ltd, London, UK). A suitable field was chosen and recorded for $30 \mathrm{~min}$ by a time-lapse video recorder at 1/60 normal speed. UCN $\left(10^{-7} \mathrm{M}\right.$ final concentration) was added in $0.5 \mathrm{ml}$ pre-warmed MEM/FCS and recording was continued for a further $60 \mathrm{~min}$.

\section{Assessment of osteoclast apoptosis and number}

Osteoclasts containing M-CSF (50 ng/ml) and RANKL $(30 \mathrm{ng} / \mathrm{ml})$ were incubated for $18 \mathrm{~h}$ with $\mathrm{UCN}\left(10^{-7} \mathrm{M}\right)$, vehicle, or exposed to u.v. light $\left(100 \mathrm{~mJ} / \mathrm{cm}^{2}\right.$ for $5 \mathrm{~min}$, as a positive control for the induction of apoptosis) and then incubated for $18 \mathrm{~h}$. Proteins were extracted and the extent of cleaved caspase 3 (Asp175) and cleaved poly (ADP-ribose) polymerase (PARP (Asp214)) (Cell Signalling) NEB, was assessed by western blotting.

Osteoclasts underwent the same experimental conditions as those in the actin ring experiments and were either untreated or treated with UCN $\left(10^{-7} \mathrm{M}\right)$ for $30 \mathrm{~min}$ and then TRAP-positive cells displaying three or more nuclei were counted.

\section{Western blotting}

Osteoclasts were lysed in RIPA buffer: Tris- $\mathrm{HCl}(50 \mathrm{mM})$, $\mathrm{pH} 8 \cdot 0, \mathrm{NaCl}(150 \mathrm{mM}), 0 \cdot 5 \%(\mathrm{w} / \mathrm{v}) \mathrm{SDS}$ and 1\% (v/v) Nonidet P-40, containing $10 \mathrm{mM}$ dithiothreitol (DTT) and protease inhibitor cocktail (Roche). Proteins were extracted and resolved on a 10\% SDS-PAGE gel and transferred onto Hybond-C nylon membrane (GE Healthcare, Chalfont St Giles, Bucks, UK). Membranes were blocked with PBS containing 4\% (w/v) Marvel (milk powder) for $30 \mathrm{~min}$. The blocking solution was removed and replaced with PBS containing 1\% (w/v) Marvel. TRPC1, actin (Alomone Labs, Jerusalem, Israel), caspase 3 and PARP primary antibodies were incubated overnight at $4{ }^{\circ} \mathrm{C}$. The next day, membranes were washed two times for $1 \mathrm{~min}$ in PBS containing $0.5 \%$ Tween and then the appropriate HRP-conjugated secondary antibody (Santa Cruz Biotechnology, Inc., Santa Cruz, CA, USA) was applied in PBS containing 1\% (w/v) Marvel and incubated for $2 \mathrm{~h}$ at room temperature. To visualise the proteins of interest, membranes were washed three times for $5 \mathrm{~min}$ in PBS containing $0.5 \%$ Tween and then exposed to ECL reagent (GE Healthcare) for $1 \mathrm{~min}$ before exposure to light sensitive film.

\section{Preparation of calvaria-derived osteoblastic cells}

Calvaria were removed from 3-day-old neonatal mice and dissected free of soft tissue and periosteum. They were incubated in PBS containing type II collagenase $(1 \mathrm{mg} / \mathrm{ml}$; type II) for $2 \mathrm{~h}$ at $37^{\circ} \mathrm{C}$ with periodic agitation. After incubation, the calvaria were further disrupted using a wide bore Pasteur pipette. The cell suspension was then combined with DMEM containing 10\% FCS and centrifuged at $400 \mathrm{~g}$ for $5 \mathrm{~min}$. The cell pellet was resuspended in DMEM/FCS and plated at the desired density for $3 \mathrm{~h}$ after which the non-adherent cells were removed and fresh media added. The cells were incubated overnight.

\section{MC3T3-E1 cells}

MC3T3-E1 osteoblastic cell line was propagated in MEM/FCS supplemented with non-essential amino acids. Cells were allowed to reach $80 \%$ confluency before experiments were conducted.

\section{Assessment of osteoclast differentiation}

M-CSF-dependent, non-adherent murine bone marrow cells were prepared as described above and harvested. $3 \times 10^{4}$ Cells were added to the wells of a 96-well plate (Greiner) containing $6 \mathrm{~mm}$ Thermonox coverslips (VWR International Ltd, Lutterworth, Leicester, UK) and incubated in $200 \mu \mathrm{l}$ MEM/FCS with M-CSF (50 ng/ml), RANKL (30 ng/ml) and TGF- $\beta 1(0.1 \mathrm{ng} / \mathrm{ml})$ in the presence or the absence of UCN $\left(10^{-9}-10^{-7} \mathrm{M}\right)$ from 1 to 5 days. After 5 days incubation, cells were fixed in $10 \%$ formalin for $10 \mathrm{~min}$ and stained for TRAP using the Leucognost-AP cytochemical reagent kit (VWR International Ltd). Osteoclast numbers were evaluated 'blind' by quantification of the number of TRAP-positive cells with three or more nuclei per square centimetre. 


\section{RT-PCR}

Total RNA was extracted from cells and tissues using Trizol reagent (Invitrogen), DNase treated and purified using RNA MinElute columns (Qiagen). One microgram of total RNA was reverse transcribed using Superscript III Reverse Transcriptase (Invitrogen) and the cDNA amplified using REDTaq ReadyMix PCR Mix, in the presence of the relevant primer sets.

\section{Assessment of osteoclastic markers}

Non-adherent bone marrow cells were incubated in MEM/FCS, M-CSF (50 ng/ml), RANKL (30 ng/ml) and TGF- $\beta(0 \cdot 1 \mathrm{ng} / \mathrm{ml})$, with or without UCN $\left(10^{-10}-10^{-7} \mathrm{M}\right)$. After 5 days osteoclasts were assessed for expression of the calcitonin receptor (CT-R), cathepsin K (Cath K), TRAP and dendritic cell-specific transmembrane protein (DC-STAMP) (Nicholson et al. 1986) and GAPDH by RT-PCR using the following primers:

CT-R:

Forward: 5'-GTCTTGCAACTACTTCTGGATGC-3'

Reverse: 5'-AAGAAGAAGTTGACCACCAGAGC-3'

Cath K:

Forward: 5'-CACGGGAAGCAGTACAACAG-3'

Reverse: 5'-AGTCATCTTCTGAACCACTTCTTC-3'

TRAP:

Forward: 5'-TCCCCTGGTATGTGCTGG-3'

Reverse: $5^{\prime}$-GCATTTTGGGCTGCTGA-3'

DC-STAMP:

Forward: 5'-CTAGCTGGCTGGACTTCATCC-3'

Reverse: 5'-TCATGCTGTCTAGGAGACCTC-3'

GAPDH:

Forward: 5'-GGTCTCGCTCCTGGAAGATG-3'

Reverse: 5'-CGGATTTGGCCGTATTGG-3'.

Expression of the UCN system and TRPC1 in bone cells

The expression of UCN, CRF receptors and CRF-BP was investigated using semi-quantitative RT-PCR as above in pre-osteoclasts, mature osteoclasts, MC3T3-E1 cells, calvaria-derived primary osteoblasts, heart and brain. Total RNA was extracted and cDNA synthesised as above and PCR was performed using the following primers:

UCN:

Forward: 5'-ACTGTCCATCGACCTCACCTTCCA-3'

Reverse: 5'-ACTGAGACAGCTCCGGTTGTGC-3'

All CRFR1 subtypes:

Forward: 5'-GGTGTGCCTTTCCCCATCATT-3'

Reverse: $5^{\prime}$-CAACATGTAGGTGATGCCCAG-3'

CRFR $2 \alpha$ specific:

Forward: $5^{\prime}$-CCTGGACGGCTGGAGTC- $3^{\prime}$

Reverse: 5'-CAGAATGAAGGTGGTGATGAGGTT-3'
CRFR $2 \beta$ specific:

Forward: $5^{\prime}$-CAGGCCAGGCACCCCAGGAC- $3^{\prime}$

Reverse: $5^{\prime}$-ACCACGCGATGTTTCTCAG-3'

CRF-BP:

Forward: 5'-AGACCATCCTCACCACAGCATT- ${ }^{\prime}$

Reverse: $5^{\prime}$-ACTTTGACCTGGTCTCCATCGACTGCCAG- $3^{\prime}$

TRPC1:

Forward: 5'-CAAGATTTTGGGAAATTTCTGG-3'

Reverse: $5^{\prime}$-TTTATCCTCATGATTTGCTAT-3'.

\section{Effect of channel blockers on actin ring formation}

Osteoclasts were incubated for $4 \mathrm{~h}$ in $200 \mu \mathrm{l}$ MEM/FCS in the presence of M-CSF $(50 \mathrm{ng} / \mathrm{ml})$, RANKL $(30 \mathrm{ng} / \mathrm{ml})$, IL1 $\beta(10 \mathrm{ng} / \mathrm{ml})$ and with one of the following: UCN $\left(10^{-7} \mathrm{M}\right)$, nicardipine $\left(10^{-6} \mathrm{M}\right)$, BayK6844 $\left(10^{-6} \mathrm{M}\right)$, $\mathrm{La}^{3+}\left(10^{-4} \mathrm{M}\right), \mathrm{Gd}^{3+}\left(10^{-4} \mathrm{M}\right)$, glibenclamide $\left(10^{-6} \mathrm{M}\right)$ for $30 \mathrm{~min}$ or vehicle and actin rings assessed as above.

\section{Electrophysiology}

Single cation channel currents were recorded from cellattached patches with an AXOpatch 200B patch-clamp amplifier (Axon Instruments, Sunnyvale, CA, USA) at room temperature. Composition of the external solution was ( $\mathrm{mM})$ $\mathrm{KCl}$ (126), $\mathrm{CaCl}_{2}(1 \cdot 5)$, HEPES (10) and glucose (11), $\mathrm{pH}$ to $7 \cdot 2$ with $10 \mathrm{M} \mathrm{KOH}$, to set the membrane potential at $\sim 0 \mathrm{mV}$. The patch pipette solution contained $(\mathrm{mM}): \mathrm{NaCl}$ (126), $\mathrm{CaCl}_{2}(1 \cdot 5)$, HEPES (10), glucose (11), TEA (10), 4-AP (5), iberiotoxin $(0 \cdot 0002)$, DIDS $(0 \cdot 1)$, niflumic acid $(0 \cdot 1)$ and nicardipine $(0 \cdot 005), \mathrm{pH}$ to $7 \cdot 2$ with $\mathrm{NaOH}$. Under these conditions voltage-dependent $\mathrm{Ca}^{2+}$ channels, $\mathrm{K}^{+}$currents, $\mathrm{Cl}^{-}$currents were abolished and non-selective cation currents were recorded in isolation. Patch pipettes were manufactured from borosilicate glass to produce pipettes with resistances of about $10 \mathrm{M} \Omega$ when filled with patch pipette solution. $I / V$ relationships of single channel currents were determined by manually altering the membrane potential between -90 and $+50 \mathrm{mV}$. For off-line analysis, single channel currents were filtered at $100-200 \mathrm{~Hz}(-3 \mathrm{db}$, low pass 8-pole Bessel filter, Frequency Devices, model LP02, Scensys Ltd, Aylesbury, UK) and acquired using a Digidata 1322A and pCLAMP 9.0 at a sample rate of $1-2 \mathrm{kHz}$. Single channel current amplitudes were calculated from idealised traces of at least $60 \mathrm{~s}$ in duration using the $50 \%$ threshold method and analysed using pCLAMP v.9.0 software, with events lasting for 3.332-6.664 ms $(\times 2$ rise time for a 100 $200 \mathrm{~Hz},-3 \mathrm{db}$, low pass Bessel filter) being excluded from analysis. Single channel current amplitude histograms were plotted and fitted with Gaussian curves with the peak of these curves determining the unitary amplitude of the single channel currents. Open probability $\left(\mathrm{NP}_{\mathrm{o}}\right)$ was calculated automatically using pCLAMP 9. Figure preparation was carried out using MicroCal Origin software 6.0 (Origin Lab 
Inc, Northampton, MA, USA) where inward single cation channel openings are shown as downward deflections.

\section{Statistical analysis}

Statistical significance was assessed using ANOVA (Dunnett's test). Differences were considered significant if $P<0 \cdot 05$. All data are expressed as mean \pm s.E.M. for at least six independent observations.

\section{Results}

UCN suppresses osteoclast differentiation, resorption and motility

Osteoclasts are large, multinucleated cells that can be distinguished from undifferentiated precursors by their ability to stain positively for TRAP. In our initial experiments, we investigated the effect of UCN on osteoclast differentiation by measuring the number of multinucleated TRAP-positive osteoclasts after 5 days incubation. Figure $1 \mathrm{~A}$ shows that UCN produced a significant reduction in the formation of mature osteoclasts, at $10^{-7} \mathrm{M}$. Osteoclasts generated in control cultures were large, round and well-spread, whereas following inclusion of UCN $\left(10^{-7} \mathrm{M}\right)$, osteoclasts contained fewer nuclei and were generally much smaller and less spread (Fig. 1B).

To further characterise the action of UCN on osteoclast differentiation, we investigated the effect of this peptide on expression levels of CT-R, Cath K, TRAP and DC-STAMP in osteoclasts using RT-PCR. UCN was included in the incubation media from 1 to 5 days. These markers are highly expressed in osteoclasts, but virtually absent in macrophages, therefore the expression of these is indicative of osteoclast maturation (Nicholson et al. 1986). Figure 1C and D demonstrates that treatment of osteoclasts with UCN produced a significant concentration-dependent reduction in CT-R, Cath K, TRAP and DC-STAMP, mRNA, measured after 5 days. In contrast, UCN had no effect on the expression level of GAPDH mRNA.
A

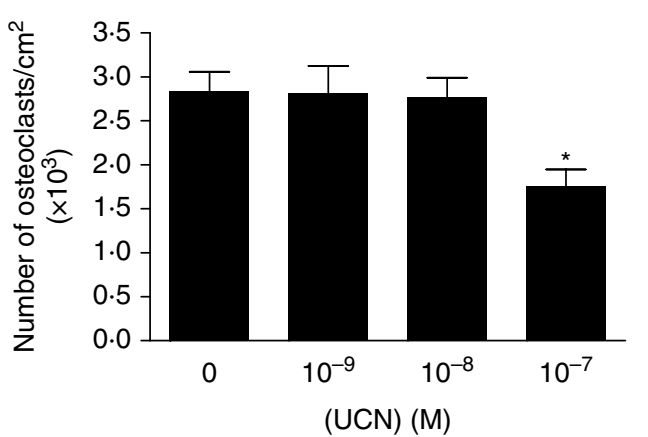

B

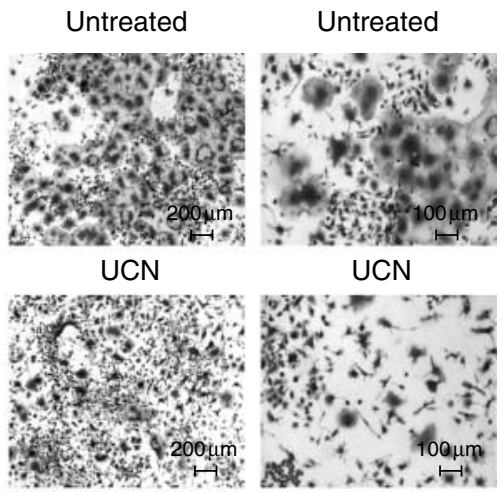

C

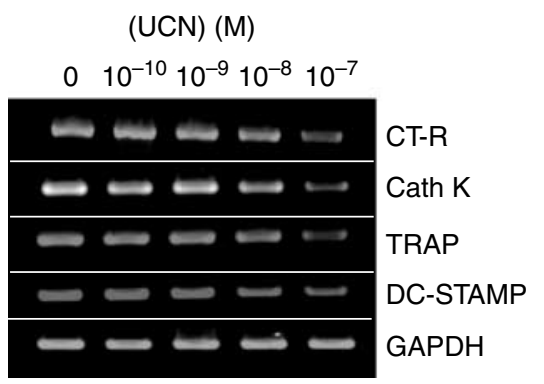

$\mathrm{D}$

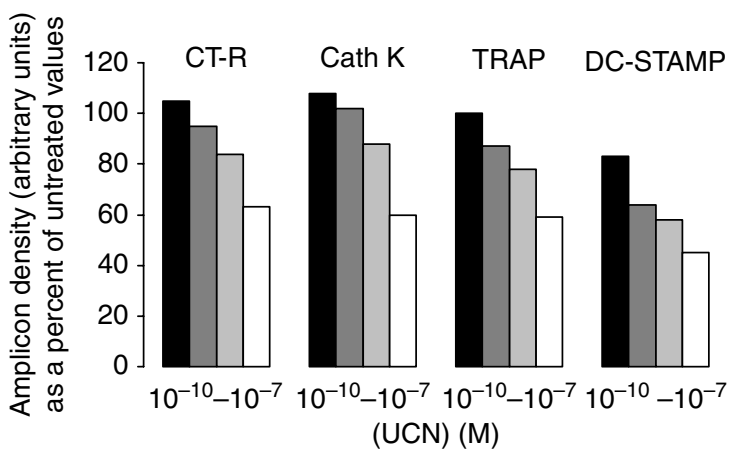

Figure 1 Effect of UCN on osteoclast differentiation. (A) Inhibition of the development of multinucleated TRAP-positive osteoclasts by UCN $\left(10^{-7} \mathrm{M}\right)$ after 5 days, $n=6$ cultures per variable ${ }^{*} P<0 \cdot 05$ vs control.

(B) Representative photomicrographs at low magnification (left) and higher magnification (right) of TRAP-positive osteoclasts formed in the absence (top panel) or presence (lower panel) of UCN $\left(10^{-7} \mathrm{M}\right)$ after 5 days.

(C) Concentration-dependent suppression of CT-R, Cath K, TRAP and DC-STAMP mRNA levels by UCN assessed by semi-quantitative RT-PCR in developing osteoclasts after 5 days, $n=3$ cultures. (D) Concentration-dependant amplicon density (arbitrary units), for CT-R, Cath K, TRAP and DC-STAMP in developing osteoclasts, expressed as a percentage of untreated values. All values were standardised to GADPH. 
UCN produced a significant concentration-dependent inhibition of osteoclastic bone resorption, with an $\mathrm{IC}_{50}$ value of $10^{-9} \mathrm{M}$ and complete abolition at $10^{-7} \mathrm{M}$ (Fig. 2A). Figure 2B depicts representative scanning electron micrographs of bone slices after cells had been exposed to UCN or vehicle. Large pits can be clearly seen in control conditions, but were not seen on bone slices incubated with UCN.

We investigated the effect of UCN on actin ring formation, a marker for osteoclast activation, in osteoclasts sedimented onto bone slices. After $4 \mathrm{~h}$, UCN was added in a dosedependent manner and the cells were further incubated for 30 min. UCN induced a significant dose-dependent reduction in actin ring formation, with an $\mathrm{IC}_{50}$ of $\sim 5 \times 10^{-10} \mathrm{M}$ and complete inhibition at $10^{-7} \mathrm{M}$ (Fig. 2C). Untreated osteoclasts produced actin ring structures that were absent after treatment with UCN (Fig. 2D).

The differences seen in the resorption experiments were not due to a toxic effect of UCN, as the number of cells within the untreated and treated groups at the end of the experiments did not differ significantly (Fig. 4B).

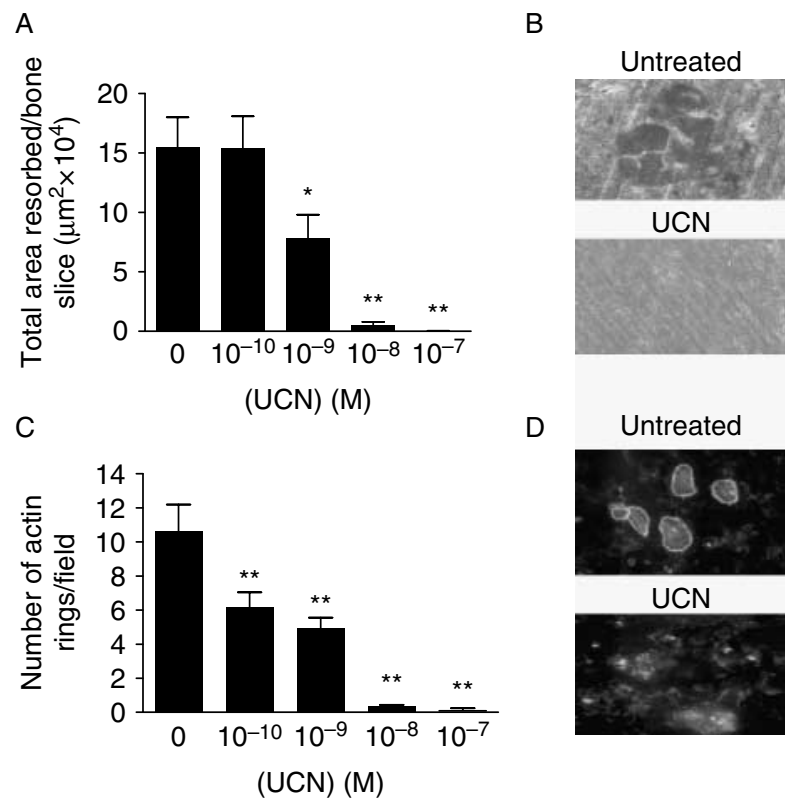

Figure 2 Effect of UCN on osteoclast function. (A) Concentrationdependent inhibition of osteoclastic bone resorption by $U C N$ after $30 \mathrm{~min}, n=6$ cultures per variable $* P<0 \cdot 05, * * P<0 \cdot 001$ vs control. (B) Representative scanning electron micrographs of resorption pits caused by resorbing osteoclasts in the absence (upper panel) or presence (lower panel) of UCN $\left(10^{-7} \mathrm{M}\right)$ after $30 \mathrm{~min}$. (C) Concentration-dependent reduction in the number of actin rings per field by UCN. Osteoclasts were incubated on bone slices in the presence of M-CSF, RANKL and IL $1 \alpha$ for $4 \mathrm{~h}$, then UCN was added at the concentrations indicated and incubation continued for $30 \mathrm{~min}, n=6$ cultures per variable ${ }^{* *} P<0 \cdot 001$ vs control. (D) Representative photomicrograph of actin rings produced by activated osteoclasts in the absence (upper panel) or presence (lower panel) of UCN $\left(10^{-7} \mathrm{M}\right)$ after $30 \mathrm{~min}$.
Movement of osteoclasts during the control incubation period was characterised by pseudopodial ruffling. Inclusion of UCN $\left(10^{-7} \mathrm{M}\right)$ markedly inhibited this ruffling activity (Fig. 3), with complete cessation of cytoplasmic motility, leading to a shape-change characteristic of motilityinhibition, similar to that caused by CT (Chambers 2010).

\section{UCN has no effect on osteoclast apoptosis or number}

UCN has been documented to have both pro- and antiapoptotic effects depending on the cell type. Therefore, we examined the effect of UCN on osteoclast apoptosis. We performed western blot analysis to determine the extent of procaspase 3 cleavage into its smaller pro-apoptotic cleaved form and PARP cleavage, both well established markers of late apoptosis. We found no difference in the amount of caspase 3, or PARP cleavage between untreated or UCNtreated osteoclasts, indicating that in these cells UCN had no effect on apoptosis. We did however, find extensive cleavage of both caspase 3 and PARP in osteoclasts undergoing u.v. irradiation (Fig. 4A). Furthermore, there was no difference in osteoclast number between untreated and UCN-treated cells (Fig. 4B).

\section{UCN and CRFR2 $\beta$, but not CRF-BP, are expressed in osteoclasts}

The expression of genes involved in UCN signalling was investigated in bone cells, we performed RT-PCR on in vitroderived pre-osteoclasts ( 0 day), osteoclasts, primary calvarial osteoblasts, the osteoblastic cell line MC3T3-E1, and heart and brain tissues as control. Figure 5 demonstrates that mRNA for the CRFR $2 \beta$ was present, but not UCN, in preosteoclasts. However, both UCN and CRFR2 $\beta$ were expressed in osteoclasts, whereas CRF-BP was absent in both pre-osteoclasts and osteoclasts, but exclusively expressed in osteoblastic cells.

\section{Non-selective cation channel blockers inhibit actin ring formation}

In other cell types, UCN has been shown to regulate cellular functions by inhibiting ion channels involved in promoting $\mathrm{Ca}^{2+}$ influx, such as voltage-dependent and -independent $\mathrm{Ca}^{2+}$-permeable channels (Tao et al. 2004, 2006, Smani et al. 2007). Extracellular $\mathrm{Ca}^{2+}$, and hence $\mathrm{Ca}^{2+}$ influx pathways, are also important for osteoclast differentiation and function (Boyce \& Xing 2007). In particular, intracellular $\mathrm{Ca}^{2+}$ levels have been shown to be important for osteoclast differentiation and notably for RANK signalling (Takayanagi et al. 2002). Therefore, $\mathrm{Ca}^{2+}$ channels are potential targets for UCN in osteoclasts. To investigate whether inhibition of a $\mathrm{Ca}^{2+}$ permeable cation channel is able to mimic UCN we studied the effect of ion channel blockers on actin ring formation. Figure 6A shows that inclusion of the L-type channel modulators BayK6844 and nicardipine, and also the $\mathrm{K}_{\mathrm{ATP}}$ channel agonist glibenclamide, had no effect on actin ring 

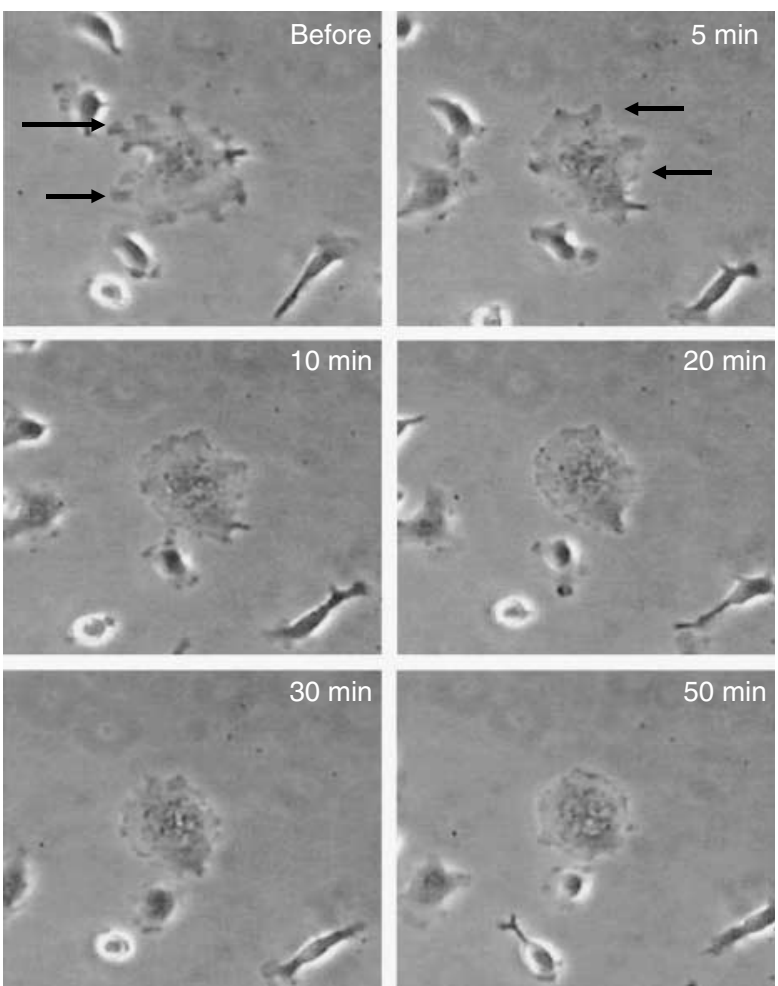

Figure 3 UCN suppresses osteoclast motility. Photomicrographs showing motility of an osteoclast before UCN $\left(10^{-7} \mathrm{M}\right)$ addition and 5, 10, 20, 30 and 50 min after addition. Arrows indicate membrane ruffling, $n=3$ cultures.

formation, whereas the non-selective cation channel blockers $\mathrm{La}^{3+}$ and $\mathrm{Gd}^{3+}$ reduced osteoclast actin ring formation to a similar degree to that of UCN.

\section{UCN inhibits a constitutively active non-selective cation channel}

Given that non-selective cation channel blockers inhibit actin ring formation to a similar level to UCN, this indicates that the inhibition of a cation channel may be involved in the inhibitory mechanism of UCN in osteoclasts. We therefore, investigated whether osteoclasts express constitutively active $\mathrm{Ca}^{2+}$-permeable cation channel activity and whether UCN inhibits this channel activity. To test this, we used standard electrophysiological patch clamp methods to record single cation channel activity in cell-attached patches from mature osteoclasts after 5 days in culture, with recordings made from large, multinucleated osteoclasts. Figure $6 \mathrm{~B}$ shows that 15 out of 20 un-stimulated patches tested contained downward current deflections, which represented constitutively active cation channel activity in osteoclasts that had a mean $\mathrm{NP}_{\mathrm{o}}$ value of $2 \cdot 42 \pm 0 \cdot 29(n=15)$ and a mean unitary amplitude of $-0 \cdot 22 \pm 0 \cdot 02(n=15)$ at $-50 \mathrm{mV}$. Mean I/V relationship of these spontaneous cation channel currents had a slope conductance of 3-4 pS, with a reversal potential of about
$+20 \mathrm{mV}$ (data not shown). It is important to note that the activity of these constitutively active cation channel currents was not regulated by altering membrane potential, which indicates that these channels are voltage-independent. Importantly, Fig. 6C shows that bath application of UCN $\left(10^{-7} \mathrm{M}\right)$ significantly inhibited constitutively active cation channel activity, with the mean $\mathrm{NP}_{\mathrm{o}}$ of channel activity being reduced from $2 \cdot 61 \pm 0.59$ to $0 \cdot 78 \pm 0 \cdot 34(n=10, P<0 \cdot 01)$ at $-50 \mathrm{mV}$, representing a mean inhibition of $70 \pm 7 \%$.

\section{Expression of TRPC1 $m R N A$ and channel protein in osteoclasts}

The spontaneously active channel currents we have identified have similar unitary conductances to previously studied canonical TRPC1-containing cation channels (Strübing et al. 2001, Alfonso et al. 2008, Saleh et al. 2008, Albert et al. 2009), and Fig. 6D shows that both i) mRNA and ii) protein for TRPC1 are highly expressed in osteoclasts.

\section{Discussion}

This work demonstrates for the first time that UCN produces marked inhibition of osteoclast differentiation and function, indicating that this peptide is a novel regulator of resorption. Our data also provide new information on the expression of a constitutively active $\mathrm{Ca}^{2+}$-permeable cation channel in osteoclasts, which has properties similar to TRPC1containing channels. Moreover, the action of UCN on osteoclasts is mediated, at least in part, by inhibition of these spontaneously active channels. Our findings illustrate that UCN significantly suppressed osteoclastic differentiation, as measured by the development of TRAP-positive, multinuclear cells at $10^{-7} \mathrm{M}$ and also lowered the mRNA levels of several osteoclastic markers: CT-R, Cath K, TRAP and DC-STAMP. UCN also caused striking inhibition of both osteoclast bone resorption and actin ring formation. In both assays, the $\mathrm{IC}_{50}$ for UCN was $\sim 10^{-9} \mathrm{M}$. Furthermore, UCN completely abolished osteoclast motility at $10^{-7} \mathrm{M}$,
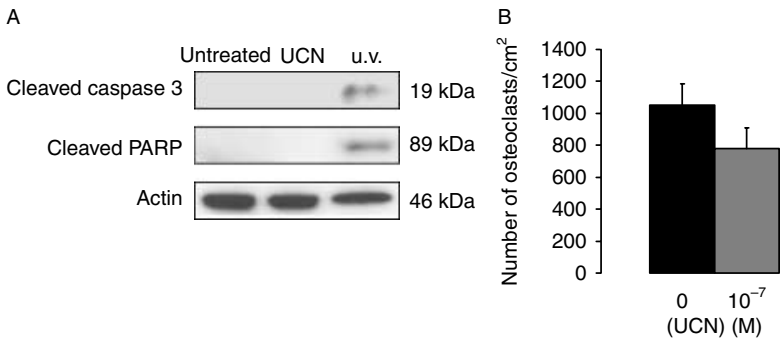

Figure 4 Effect of $U C N$ on osteoclast apoptosis and number. (A) Western blot assessing the extent of caspase 3 (Asp175) and PARP (Asp214) cleavage products in untreated, UCN $\left(10^{-7}\right)$ treated $18 \mathrm{~h}$ and u.v.-irradiated osteoclasts. (B) Osteoclasts were incubated on bone slices in the presence of M-CSF, RANKL and IL $1 \alpha$ for $4 \mathrm{~h}$, then vehicle or UCN $\left(10^{-7} \mathrm{M}\right)$ was added for $30 \mathrm{~min}, n=3$ cultures. 


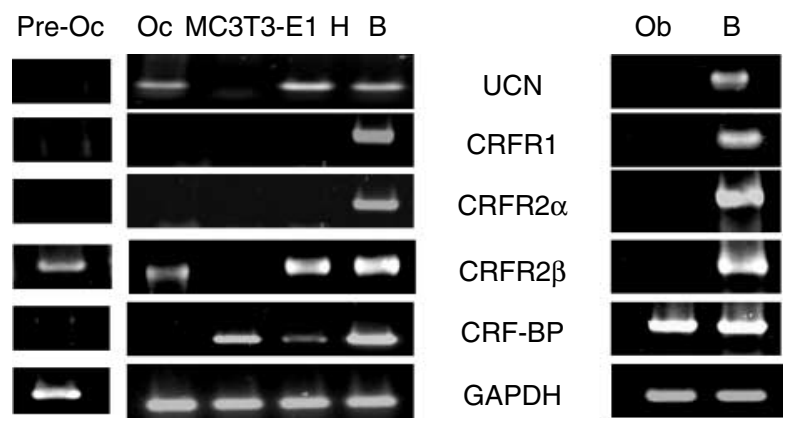

Figure 5 Expression of a UCN system in bone cells. (A) RT-PCR using primers designed to amplify UCN, CRFR1, CRFR2 $\alpha$, CRFR2 $\beta$, CRF$\mathrm{BP}$ and GAPDH in pre-osteoclasts (pre-Oc), mature osteoclasts (Oc), the osteoblast cell line MC3T3-E1 (MC3T3-E1), heart $(\mathrm{H})$ and brain (B) as positive controls and primary osteoblasts (Ob), $n=3$ cultures.

but had no effect on osteoclast apoptosis as measured by caspase 3 and PARP cleavage, both indicators of late apoptotic events (Ferrer \& Planas 2003, Agarwal et al. 2009) or osteoclast number.

The plasma concentration of $\mathrm{UCN}$ is in a similar range to the $\mathrm{IC}_{50}$ value for the inhibition of actin ring formation (Charles et al. 2006, Torricelli et al. 2006). Therefore, bone resorption might be regulated in vivo by systemic UCN. Alternatively our results raise the possibility that there might be a local UCN system in bone, and that osteoclasts might be regulated by this.

Our findings show that UCN mRNA is expressed in osteoclasts but not in primary osteoblasts or the osteoblast cell line, MC3T3-E1. We also found, using isoform-specific primers, that osteoclasts express the CRFR $2 \beta$ receptor subtype, which is commonly expressed in peripheral tissues (Perrin et al. 1995, Fekete \& Zorrilla 2007). In contrast, CRF-BP was expressed by primary osteoblasts and MC3T3E1 cells but not osteoclasts. Unlike osteoclasts, we found that pre-osteoclasts expressed CRFR $2 \beta$ but not UCN itself. This is in contrast to a study by Tezval et al. (2009), demonstrating the presence of UCN in human mesenchymal progenitor cells, but these cells had been directed toward an osteoblastic phenotype. Our findings suggest that UCN might represent an autocrine regulator of osteoclast function and a paracrine regulator of maturation and the concentration of UCN in the surrounding milieu could be controlled by osteoblastic CRF-BP release. At present the existence of other UCN members in bone is unknown. It would be of great interest therefore, to determine the presence of UCN 2 and 3 in osteoclasts and osteoblasts and determine their effect on function.

Recently, bone has been found to be intimately involved in the control of energy metabolism (Martin 2007, Fukumoto \& Martin 2009, Yadav \& Karsenty 2009). From this perspective it is intriguing to note that the actions of $\mathrm{UCN}$ on osteoclasts

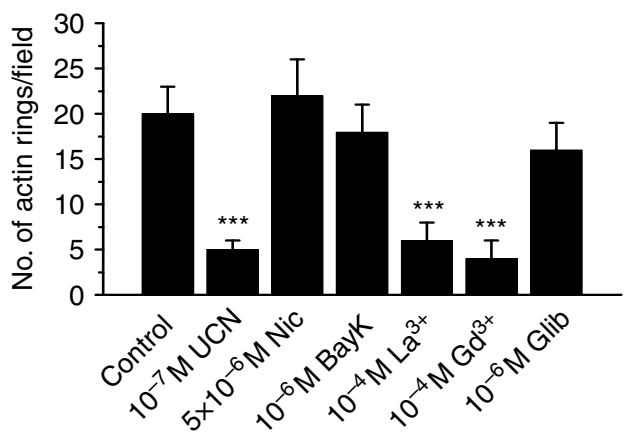

C

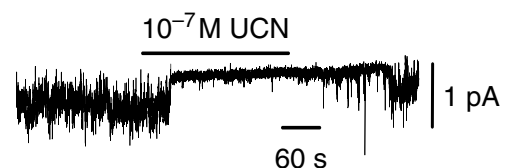

\section{Constitutively active cation channel activity at $-50 \mathrm{mV}$}

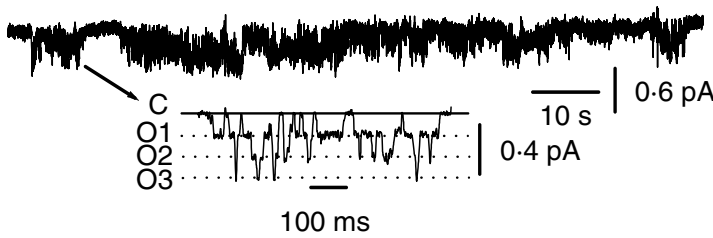

D

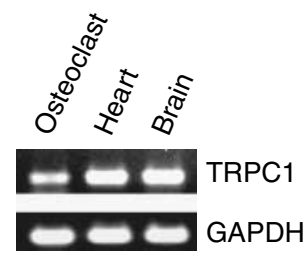

(ii)

Osteoclast

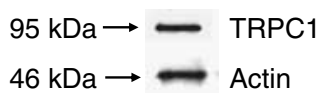

Figure 6 Osteoclasts express a constitutively active TRPC1-like cation channel currents which are inhibited by UCN. (A) UCN (10 $\left.{ }^{-7} \mathrm{M}\right)$, $\mathrm{La}^{3+}\left(10^{-4} \mathrm{M}\right)$ and $\mathrm{Gd}^{3+}\left(10^{-4} \mathrm{M}\right)$ after 30 min significantly inhibited the number of actin rings per field by a similar extent $(* * * P<0 \cdot 001 \mathrm{vs}$ control). Nicardipine $\left(\mathrm{Nic}, 5 \times 10^{-6} \mathrm{M}\right)$, BayK8644 (BayK, $\left.10^{-5} \mathrm{M}\right)$ and glibenclamide $\left(\mathrm{Glib}, 10^{-6} \mathrm{M}\right)$ had no effect on actin ring formation. $n=3$ cultures per variable. (B) Patch clamp recording from osteoclasts reveal 15 out of 20 un-stimulated patches tested contained downward current deflections, which represented constitutively active cation channel activity in osteoclasts that had a mean $\mathrm{NP}_{\mathrm{o}}$ value of $2 \cdot 42 \pm 0 \cdot 29$ $(n=15)$ and a mean unitary amplitude of $-0 \cdot 22 \pm 0 \cdot 02(n=15)$ at $-50 \mathrm{mV}$. (C) Bath application of UCN $\left(10^{-7} \mathrm{M}\right)$ significantly inhibited constitutively active cation channel activity, with the mean $\mathrm{NP}_{\mathrm{O}}$ of channel activity being reduced from $2 \cdot 61 \pm 0 \cdot 59$ to $0 \cdot 78 \pm 0 \cdot 34(n=10$, $P<0.01$ ) at $-50 \mathrm{mV}$, representing a mean inhibition of $70 \pm 7 \%$. (D) Osteoclasts express i) TRPC1 mRNA and ii) TRPC1 protein, using RT-PCR and western blotting methods respectively. 


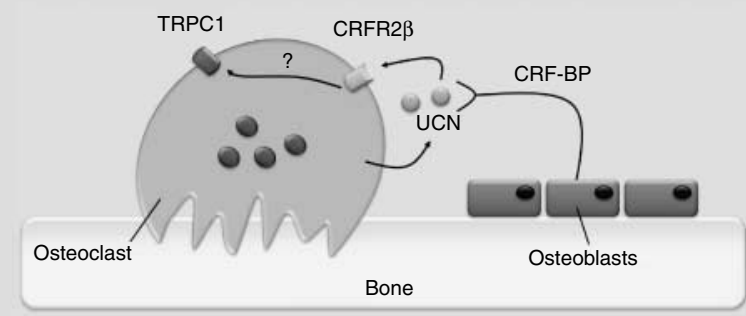

Figure 7 Schematic representation of the novel UCN/ CRF-BP pathway in bone. In response to unknown stimuli, $U C N$ is released from, and acts upon osteoclasts in an autocrine manner, through binding to cell surface CRFR2 $\beta$ receptors. This causes the closure of a constitutively active TRPC1-like cation channel, resulting in the inhibition of osteoclast resorption. The biochemical cascade coupling CRFR2 $\beta$ receptors to closure of TRPC1 channels is currently unknown. The inhibitory effect of UCN is likely to be attenuated by the release, through unknown stimuli, of CRF-BP from osteoblasts.

may represent an additional component of this system. Systemic administration of UCN was shown to inhibit weight gain and decrease visceral fat of obese mice (Asakawa et al. 1999, Richard et al. 2000, Kuperman \& Chen 2008). Furthermore, UCN, which crosses the blood-brain barrier, has potent actions as a regulator of appetite.

CRF receptors have been shown to activate several intracellular pathways, both in vivo and in vitro. CRFR1 and 2 are coupled to $G_{\alpha s}$ G-proteins, leading to activation of $\mathrm{AC}$ and subsequent cAMP-dependent protein kinase A. They can also be linked to $G_{\alpha q}$ proteins, activating PLC that generates inositol-1,4,5-trisphosphate and diacylglycerol, causing the release of $\mathrm{Ca}^{2+}$ from internal $\mathrm{Ca}^{2+}$ stores and stimulating protein kinase $\mathrm{C}$-dependent pathways respectively (Graziani et al. 2002, McEvoy et al. 2002). However, other pathways have been reported to be activated by stimulation of CRFRs such as (ERK)-MAP kinase, AKT/protein kinase B and nitric oxide synthase-guanylyl cyclase (Grammatopoulos et al. 2000, Cantarella et al. 2001, Bayatti et al. 2003, Karteris et al. 2005). The intracellular signalling pathways activated by UCN in osteoclasts remain unknown, but intracellular $\mathrm{Ca}^{2+}$ signalling has been shown to be crucial for maintaining osteoclastic differentiation (Boyce \& Xing 2007) and UCN has been shown to inhibit store-operated $\mathrm{Ca}^{2+}$ entry in vascular smooth muscle cells (Smani et al. 2007, Negishi-Koga \& Takayanagi 2009). Therefore, channels that regulate $\mathrm{Ca}^{2+}$ entry are potential candidates as a target for $\mathrm{UCN}$ in osteoclasts.

The present study shows that osteoclasts express constitutively active cation channel currents, which have a unitary conductance between $3-4 \mathrm{pS}$ and an $\mathrm{E}_{\mathrm{rev}}$ of $+25 \mathrm{mV}$ that indicates significant permeability to $\mathrm{Ca}^{2+}$ ions. The distinctive single channel properties of these channel currents in osteoclasts are similar to previously described TRPC1-containing channels (Strübing et al. 2001, Alfonso et al. 2008, Saleh et al. 2008). Furthermore, we also demonstrate the presence of mRNA, and protein for TRPC1 subunit in mature osteoclasts. This is the first direct evidence that a functional cation conductance with TRPC-like properties is expressed in mature osteoclasts. We currently do not understand the mechanisms driving constitutive channel activity in osteoclasts, although constitutive $G_{\alpha_{\mathrm{i}} / \mathrm{o}}$ protein activity evokes TRPC3 channel activity through PLD-mediated generation of DAG in vascular smooth muscle (Albert \& Large 2003, Albert et al. 2005). Furthermore, the function of spontaneously opening $\mathrm{Ca}^{2+}$ channels, which are likely to induce $\mathrm{Ca}^{2+}$ entry, is also unknown. TRPV4 channel activity has been implicated in the maintenance of intracellular $\mathrm{Ca}^{2+}$ needed for nuclear factor of activated T-cells (NFAT) activation for osteoclast differentiation (Masuyama et al. 2008), and the RANKL-induced $\mathrm{Ca}^{2+}$ increase may also, in part, have extracellular origins, possibly through activation of TRPV5 channels (Bennett et al. 2001, van der Eerden et al. 2005, Chamoux et al. 2010). It is tempting therefore, to speculate that this constitutively active current is also involved in the maintenance of NFAT expression/activity in osteoclasts.

Our results clearly show that UCN, at similar concentrations to those levels producing inhibitory actions on osteoclast differentiation and function, induced a pronounced suppression of the constitutively active channel activity. In addition, $\mathrm{La}^{3+}$ and $\mathrm{Gd}^{3+}$, which are non-selective cation channel blockers that inhibit activity of many different cation channels, also produced a marked inhibition of actin ring formation to a similar level to UCN. In comparison, nicardipine, which blocks L-type $\mathrm{Ca}^{2+}$ channels, BayK8644 an L-type $\mathrm{Ca}^{2+}$ channel opener and glibenclamide a $\mathrm{K}_{\text {ATP }}$ channel opener, had no effect on actin ring formation. An intriguing hypothesis derived from our work is illustrated in Fig. 7, in which the UCN-mediated system described in the present study shows similarities to the wellestablished RANKL/osteoprotegerin system in bone, in that both systems employ a decoy receptor derived from osteoblasts to terminate an osteoclast-targeted ligand signal (Chambers 2010). Importantly however, the UCN system demonstrates an alternative regulatory pathway for osteoclastogenesis and activity, in that this system antagonises the effects of RANKL, resulting in the inhibition of osteoclast differentiation and activity.

In conclusion, this study shows that osteoclast differentiation and function are markedly inhibited by UCN, and that UCN, its binding protein and receptor are expressed by bone cells. This suggests that bone contains a local UCN system that might modulate local and/or systemic bone resorption in response to as-yet unidentified signals. 
Moreover, our results indicate that the inhibitory actions of UCN on bone resorption are mediated, at least in part, by a reduction in constitutively active cation channel activity that has similar properties to TRPC1-containing channels. Importantly, manipulation of UCN levels, the UCN signalling system and activity of constitutively active channels may represent new therapeutic targets for bone disorders such as osteoporosis.

\section{Declaration of interest}

The authors declare that there is no conflict of interest that could be perceived as prejudicing the impartiality of the research reported.

\section{Funding}

This work was supported by Arthritis Research UK (grant number 18733).

\section{References}

Agarwal A, Mahfouz RZ, Sharma RK, Sarkar O, Mangrola D \& Mathur PP 2009 Potential biological role of poly (ADP-ribose)polymerase (PARP) in male gametes. Reproductive Biology and Endocrinology 7 143. (doi:10.1186/ 1477-7827-7-143)

Albert AP \& Large WA 2003 Store operated $\mathrm{Ca}^{2+}$ - permeable non-selective cation channels in smooth muscle cells. Cell Calcium 33 345-356. (doi:10. 1016/S0143-4160(03)00048-4)

Albert AP, Piper AS \& Large WA 2005 Role of phospholipase D and diacylglycerol in activating constitutive TRPC-like cation channels in rabbit ear artery myocytes. Journal of Physiology 566 769-780. (doi:10.1113/ jphysiol.2005.090852)

Albert AP, Saleh SN \& Large WA 2009 Identification of canonical transient receptor potential (TRPC) channel proteins in native vascular smooth muscle cells. Current Medicinal Chemistry 16 1156-1165. (doi:10.2174/ 092986709787581815)

Alfonso S, Benito O, Alicia S, Angélicia Z, Patricia G, Diana K \& Vaca L 2008 Regulation of the cellular localization and function of human transient receptor potential channel 1 by other members of the TRPC family. Cell Calcium 43 375-387. (doi:10.1016/j.ceca.2007.07.004)

Asakawa A, Inui A, Ueno N, Makino S, Fujino MA \& Kasuga M 1999 Urocortin reduces food intake and gastric emptying in lean and ob/ob obese mice. Gastroenterology 116 1487-1489. (doi:10.1016/S00165085(99)70491-9)

Bayatti N, Zschocke J \& Behl C 2003 Brain region-specific neuroprotective action and signaling of corticotropin-releasing hormone in primary neurons. Endocrinology 144 4051-4060. (doi:10.1210/en.2003-0168)

Behan DP, De Souza EB, Lowry PJ, Potter E, Sawchenko P \& Vale WW 1995 Corticotropin releasing factor (CRF) binding protein: a novel regulator of CRF and related peptides. Frontiers in Neuroendocrinology 16 362-382. (doi:10.1006/frne.1995.1013)

Bennett BD, Alvarez U \& Hruska KA 2001 Receptor-operated osteoclast calcium sensing. Endocrinology 142 1968-1974. (doi:10.1210/en.142.5. 1968)

Boyce BF \& Xing L 2007 Biology of RANK, RANKL and osteoprotegerin. Arthritis Research and Therapy 9 (Suppl 1) S1. (doi:10.1186/ar2165)

Brar BK, Stephanou A, Knight RA \& Latchman DS 2002 Activation of protein kinase $\mathrm{B} / \mathrm{Akt}$ by urocortin is essential for its ability to protect cardiac cells against hypoxia/reoxygenation-induced cell death. Journal of Molecular and Cellular Cardiology 34 483-492. (doi:10.1006/jmcc.2002. 1529)

Cantarella G, Lampereur L, Lombardo G, Chiarenza A, Pafumi C, Zappalà G \& Bernardini R 2001 Divergent effects of corticotropin releasing hormone on endothelial cell nitric oxide synthase are associated with different expression of CRH type 1 and 2 receptors. British Journal of Pharmacology 134 837-844. (doi:10.1038/sj.bjp.0704322)

Chambers TJ 2010 The birth of the osteoclast. Annals of the New York Academy of Sciences 1192 19-26. (doi:10.1111/j.1749-6632.2009.05224.x)

Chamoux E, Bisson M, Paylet MD \& Roux S 2010 TRPV-5 mediates a receptor activator of NF-kappaB (RANK) ligand-induced increase in cytosolic $\mathrm{Ca}^{2+}$ in human osteoclasts and down-regulates bone resorption. Journal of Biological Sciences 285 25354-25362. (doi:10.1074/jbc.M109. 075234)

Charles CJ, Rademaker MT, Mark Richards AM \& Yandle TG 2006 Plasma urocortin I in sheep: regional sampling and effects of experimental heart failure. Peptides 27 1801-1805. (doi:10.1016/j.peptides.2005.12.010)

Chen R, Lewis KA, Perrin MH \& Vale WW 1993 Expression cloning of a human corticotropin-releasing-factor receptor. PNAS 90 8967-8971. (doi:10.1073/pnas.90.19.8967)

Fekete EM \& Zorrilla EP 2007 Physiology, pharmacology, and therapeutic relevance of urocortins in mammals: ancient CRF paralogs. Frontiers in Neuroendocrinology 28 1-27. (doi:10.1016/j.yfrne.2006.09.002)

Ferrer I \& Planas AM 2003 Signaling of cell death and cell survival following focal cerebral ischaemia: life and death struggle in the penumbra. Journal of Neuropathology and Experimental Neurology 62 329-339.

Fukumoto S \& Martin TJ 2009 Bone as an endocrine organ. Trends in Endocrinology and Metabolism 20 230-236. (doi:10.1016/j.tem.2009.02.001)

Fuller K, Kirstein B \& Chambers TJ 2006 Murine osteoclast formation and function: differential regulation by humoral agents. Endocrinology 147 1979-1985. (doi:10.1210/en.2005-1340)

Gonzalez-Rey E, Chorny A, Varela N, O’Valle F \& Delgado M 2007 Therapeutic effect of urocortin on collagen induced arthritis by downregulation of inflammatory and Th1 responses and induction of regulatory T cells. Arthritis and Rheumatism 56 31-543. (doi:10.1002/art.22394)

Grammatopoulos DK, Randeva HS, Levine MA, Katsanou ES \& Hillhouse EW 2000 Urocortin, but not corticotropin-releasing hormone (CRH), activates the mitogen-activated protein kinase signal transduction pathway in human pregnant myometrium: an affect mediated via R1 and R2 CRH receptor subtypes and stimulation of Gq-proteins. Molecular Endocrinology $\mathbf{1 4}$ 2076-2091. (doi:10.1210/me.14.12.2076)

Graziani G, Tentori L, Portarena I, Barbarino M, Tringali G, Pozzoli G \& Navarra P 2002 CRH inhibits cell growth of human endometrial adenocarcinoma cells via CRH-receptor 1-mediated activation of cAMPPKA pathway. Endocrinology 143 807-813. (doi:10.1210/en.143.3.807)

Hauger RL, Grigoriadis DE, Dallman MF, Plotsky PM, Vale WW \& Dauzenberg FM 2003 International Union of Pharmacology. XXXVI 2003 Current status of the nomenclature for receptors for the corticotropinreleasing factor and their ligands. Pharmacological Reviews 55 21-26. (doi:10. $1124 /$ pr.55.1.3)

Hsu SY \& Hsueh AJ 2001 Human stresscopin and stresscopin-related peptide are selective ligands for the type 2 corticotropin-releasing hormone receptor. Nature Medicine 7 605-611. (doi:10.1038/87936)

Karteris E, Vatish M, Hillhouse EW \& Grammatopoulos DK 2005 Preeclampsia is associated with impaired regulation of the placental nitric oxide-cyclic guanosine monophosphate pathway by corticotropin-releasing hormone (CRH) and related peptides. Journal of Clinical Endocrinology and Metabolism 90 3680-3687. (doi:10.1210/jc.2004-2210)

Kohno M, Kawahito Y, Tsubouchi Y, Hashiramoto A, Yamada R, Inoue KI, Kusaka Y, Kubo T, Elenkov IJ, Chrousos GP et al. 2001 Urocortin expression in synovium of patients with rheumatoid arthritis and osteoarthritis: relation to inflammatory activity. Journal of Clinical Endocrinology and Metabolism 86 4344-4352. (doi:10.1210/jc.86.9.4344)

Kuperman Y \& Chen A 2008 Urocortins: emerging metabolic and energy homeostasis perspectives. Trends in Endocrinology and Metabolism 19 122-129. (doi:10.1016/j.tem.2007.12.002)

Lawrence KM \& Latchman DS 2006 The urocortins: mechanisms of cardioprotection and therapeutic potential. Medicinal Chemistry $\mathbf{1 0}$ $1119-1126$.

Lawrence KM, Chanalaris A, Scarabelli T, Hubank M, Pasini E, Townsend PA, Comini L, Ferrari R, Tinker A, Stephanou A et al. 2002 K(ATP) channel 
gene expression is induced by urocortin and mediates its cardioprotective effect. Circulation 106 1556-1562. (doi:10.1161/01.CIR.0000028424. 02525.AE)

Lewis K, Li C, Perrin MH, Blount A, Kunitake K, Donaldson C, Vaughan J, Reyes TM, Gulyas J, Fischer W et al. 2001 Identification of urocortin III, an additional member of the corticotropin-releasing factor (CRF) family with high affinity for the CRF2 receptor. PNAS 98 7570-7575. (doi:10.1073/ pnas.121165198)

Lovenberg TW, Liaw CW, Grigoriadis DE, Clevenger W, Chalmers DT, De Souza EB \& Oltersdorf T 1995 Cloning and characterisation of a functionally distinct corticotropin-releasing factor receptor subtype from rat brain. PNAS 92 836-840. (doi:10.1073/pnas.92.3.836)

Martin JT 2007 A skeleton key to metabolism. Nature Medicine 13 1021-1023. (doi:10.1038/nm0907-1021)

Masuyama R, Vriens J, Voets T, Karashima Y, Owsianik G, Vennekens R, Lieben L, Torrekens S, Moermans K, Vanden Bosch A et al. 2008 TRPV4mediated calcium influx regulates terminal differentiation of osteoclasts. Cell Metabolism 8 257-265. (doi:10.1016/j.cmet.2008.08.002)

McEvoy AN, Bresnihan B, Fitzgerald O \& Murphy EP 2002 Corticotropinreleasing hormone signaling in synovial tissue vascular endothelium is mediated through the cAMP/CREB pathway. Annals of the New York Academy of Sciences 966 119-130. (doi:10.1111/j.1749-6632.2002. tb04209.x)

Negishi-Koga T \& Takayanagi H $2009 \mathrm{Ca}^{2+}$-NFATc1 signalling is an essential axis of osteoclast differentiation. Immunological Reviews $\mathbf{2 3 1}$ 241-256. (doi:10.1111/j.1600-065X.2009.00821.x)

Nicholson GC, Moseley JM, Sexton PM, Mendelsohn FA \& Martin TJ 1986 Abundant calcitonin receptors in isolated rat osteoclasts. Biochemical and autoradiographic characterization. Journal of Clinical Investigation $\mathbf{7 8}$ 355-360. (doi:10.1172/JCI112584)

Perrin MH \& Vale WW 1999 Corticotropin releasing factor receptors and their ligand family. Annals of the New York Academy of Sciences 885 312-328. (doi:10.1111/j.1749-6632.1999.tb08687.x)

Perrin M, Donaldson C, Chen R, Blount A, Berggren T, Bilezikjian LM, Sawchenko P \& Vale W 1995 Identification of a second corticotropinreleasing factor gene and characterisation of a cDNA expressed in heart. PNAS 92 2969-2973. (doi:10.1073/pnas.92.7.2969)

Reyes TM, Lewis K, Perrin MH, Kunitake KS, Vaughan J, Arias CA, Hogenesch JB, Gulyas J, Rivier J, Vale WW et al. 2001 Urocortin II: a member of the corticotropin-releasing factor (CRF) neuropeptide family that is selectively bound by type 2 CRF receptors. PNAS 98 2843-2848. (doi:10.1073/pnas.051626398)

Richard D, Huang Q \& Timofeeva E 2000 The corticotropin-releasing hormone system in the regulation of energy balance in obesity. International Journal of Obesity and Related Metabolic Disorders 24 (Suppl 2) S36-S39.

Saleh SN, Albert A, Peppiat-Wildman CM \& Large WA 2008 Diverse properties of store-operated TRPC channels activated by protein kinase C in vascular myocytes. Journal of Physiology 586 2463-2476. (doi:10.1113/ jphysiol.2008.152157)

Seasholtz AF, Valverde RA \& Denver RJ 2002 Corticotropin-releasing hormone-binding protein: biochemistry and function from fishes to mammals. Journal of Endocrinology 175 89-97. (doi:10.1677/joe.0.1750089)

Smagin GN, Howell LA, Ryan DH, De Souza EB \& Harris RB 1998 The role of CRF2 receptors in corticotropin-releasing factor- and urocortininduced anorexia. Neuroreport 9 1601-1606. (doi:10.1097/00001756199805110-00063)

Smani T, Domínguez-Rodríguez A, Hmadcha A, Calderón-Sánchez E, Horrrillo-Ledesmaa A \& Ordóńez A 2007 Role of $\mathrm{Ca}^{2+}$-independent phospholipase A2 and store-operated pathway in urocortin-induced vasodilatation of rat coronary artery. Circulation Research 101 1194-1203. (doi:10.1161/CIRCRESAHA.107.159053)

Spina M, Merlo-Pich E, Chan RK, Basso AM, Rivier J, Vale WW \& Koob GF 1996 Appetite-suppressing effects of urocortin, a CRF related peptide. Science 273 1561-1564. (doi:10.1126/science.273.5281.1561)

Strübing C, Krapivinsky G, Krapivinsky L \& Clapham DE 2001 TRPC1 and TRPC5 form a novel cation channel in mammalian brain. Neuron 29 645-655. (doi:10.1016/S0896-6273(01)00240-9)

Takayanagi H, Kim S, Koga T, Nishina H, Isshiki M, Yoshida H, Saiura A, Isobe M, Yokochi T, Inoue JI, Wagner EF, Mak TW, Kodama T \& Taniguchi T 2002 Induction and activation of the transcription factor NFATc1 (NFAT2) integrate RANKL signaling in terminal differentiation of osteoclasts. Developmental Cell 3 889-901. (doi:10.1016/S1534-5807 (02)00369-6)

Tanaka C, Asakawa A, Ushikai M, Sakoguchi T, Amitani H, Terashi M, Cheng K, Chaolu H, Nakamura N \& Inui A 2009 Comparison of the anorexigenic activity of CRF family peptides. Biochemical and Biophysical Research Communications 390 887-891. (doi:10.1016/j.bbrc.2009.10.069)

Tao J, Xu H, Yang C, Liu CN \& Li S 2004 Effect of urocortin on L-type calcium currents in the adult rat ventricular myocytes. Pharmacological Research 50 471-476. (doi:10.1016/j.phrs.2004.05.006)

Tao J, Zhang Y, Soong TW \& Li S 2006 Expression of urocortin 2 and its inhibitory effects on intracellular $\mathrm{Ca}^{2+}$ via L-type voltage-gated calcium channels in rat pheochromocytoma (PC12) cells. Neuropsychopharmacology 31 2600-2609. (doi:10.1038/sj.npp.1301123)

Tezval M, Hossein T, Dresing K, Struermer EK, Blaschke M, Stuermer KM \& Siggelkow H 2009 Differentiation dependent expression of urocortin's mRNA and peptide in human osteoprogenitor cells: influence of BNP-2, TGF-beta-1 and dexamethasone. Journal of Molecular Histology 40 331-341. (doi:10.1007/s10735-009-9244-z)

Torricelli M, Ignacchitti E, Giovannelli A, Merola A, Scarpetti E, Calonaci G, Picciolini E, Florio P, Reis FM, Linton EA et al. 2006 Maternal corticotropinreleasing factor and urocortin levels in post-term pregnancies. European Journal of Endocrinology 154 281-285. (doi:10.1530/eje.1.02091)

Uzuki M, Sasano H, Muramatsu Y, Totsune K, Takahashi K, Oki Y, Lino K \& Sawai T 2001 Urocortin in the synovial tissue of patients with rheumatoid arthritis. Clinical Science 100 577-589. (doi:10.1042/CS20000242)

Väänänen HK, Zhao H, Mulari M \& Halleen JM 2000 The cell biology of osteoclast function. Journal of Cell Science 113 377-381.

Van der Eerden BC, Hoenderop JG, de Vries TJ, Schoenmaker T, Buurman CJ, Uitterlinden AG, Pols HA, Bindels RJ \& van Leeuwen JP 2005 The epithelial $\mathrm{Ca}^{2+}$ channel TRPV5 is essential for proper osteoclastic bone resorption. PNAS 102 17507-17512. (doi:10.1073/pnas.0505789102)

Vaughan J, Donaldson C, Bittencourt J, Perrin MH, Lewis K, Sutton S, Chan R, Turnbull AV, Lovejoy D, Rivier C et al. 1995 Urocortin, a mammalian neuropeptide related to fish urotensin I and to corticotropin-releasing factor. Nature 378 287-292. (doi:10.1038/378287a0)

Yadav VK \& Karsenty G 2009 Leptin-dependent co-regulation of bone and energy metabolism. Aging 1 954-956.

Received in final form 2 November 2011

Accepted 14 November 2011

Made available online as an Accepted Preprint 14 November 2011 